\title{
The Revival of Indonesian Skin Care Brands
}

\author{
Priscilla Evelyn Budiono ${ }^{1}$, Dhyah Harjanti ${ }^{1 *}$, and Karina Stankevica ${ }^{2}$ \\ ${ }^{1}$ Department of Management, Faculty of Business and Economics, Petra Christian University \\ Jl. Siwalankerto 121-131, Surabaya 60236, Indonesia \\ ${ }^{2}$ Department of Environmental Science, University of Latvia, Riga LV-1050, Latvia
}

\begin{abstract}
Skincare business in Indonesia has been growing enormously in the last decade, with the coming of international brands and the struggling of local brands, to win the Indonesian customers. The aim of this research is to analyze the influence of country of origin to purchase decision through the brand image, and the impact of country of origin on customer satisfaction for local Indonesian skin care brands. As this research is using the quantitative approach, the data are collected by using questionnaires which are distributed to selected samples of 179 respondents. The respondents are chosen from the consumers of Indonesian brands of skin care products. The data are analyzed with SmartPLS software. The results show that the country of origin has a positive influence to purchase decision, the country of origin has a positive influence on brand image, brand image has a positive influence on purchase decision, and, finally, brand image has a positive influence on customer satisfaction on local Indonesian brands of skin care products.
\end{abstract}

Keywords: Brand image, country of origin image, customer satisfaction, purchase decision.

\section{Introduction}

Recently, the advance of technology has changed the face of the manufacturing industry. The technological changes also bring some impacts on the production line of the beauty industry, especially skincare products. The results of a survey conducted by ZAP Clinic and MarkPlus Inc. [1] show the tendency of skincare consumers in Indonesia to choose foreign skin care products. Out of the six most-used skincare brands in Indonesia, the Indonesian skin care products have ranked the sixth, under the Japanese, South Korean, and British brands. This is because foreign-made products are considered to have been produced with advanced technology, resulting in better quality products. Besides, Indonesian consumers also feel more prestige when using foreign products.

Before deciding to buy a product, potential customers usually consider various aspects, one of which is the country of origin (COO) of the product. The country of origin is generally considered as a part of the characteristics of a product. The origin countries of a product will create perceptions of product quality, whether good and bad, in the minds of consumers [2,3]. According to Kotler and Keller, a country of origin image is an association and a person's mental belief in a product that is triggered by the country of

\footnotetext{
*Corresponding author: dhyah@petra.ac.id
} 
origin of the product [4]. Another understanding comes from Martin and Eroglu, who argue that a country's image is all descriptive, inferential, informational beliefs that a person has about a certain country [5]. This belief can be formed through direct experiences with a country when visiting that country or through others' experiences when using products originating from certain countries.

A person's buying behavior can be influenced by the country of origin of the product or service [6]. The country of origin image perception is a mental association and a person's belief that is triggered by a country. This perception can be a feature in making a decision or influence other characteristics in the process [4]. Consumers tend to build stereotypical impressions about a country and the products produced by that country. Czinkota and Ronkainen said when consumers realize the country of origin of a product, they can react positively or negatively [7]. This reaction is influenced by several factors, namely: (i) the origin of the appraiser and the product category being assessed, (ii) the country of origin of the company and the location of the product manufacturing, (iii) the country of origin phenomenon changing over time, depending on the phenomenon of the country in the industry it is working on, and (iv) consumers' tendency to discriminate against products influenced by demographic factors, for example, older residents and people with low education tend to avoid foreign products.

The country of origin image can be measured by, first of all, the advancement of the technology, namely the use of technology in making a product. The advanced technology can be measured through the technology developing level. Second, the prestige, which is related to the prestige of using a product. Prestige can be seen through the self-confident level for owning a certain product. Third is related to the workmanship, or related to the manufacture of a product, which included in the workmanship is the idea of product quality and product reliability. Finally, the country of origin image can be measured by the economic conditions of the product-making countries [8].

In facing global competition, local skin care producers must compete with international skin care brands. To be able to excel in such intense competition in the beauty products industry, one important aspect is to build a good brand image in the mind of consumers. Through the country of origin image of a product, consumers will also evaluate the image of the brand itself. When purchasing a product, consumers not only see the advantages offered but also tend to see the brand of the product they buy [9]. A good brand image can provide a special attraction for consumers. The stronger the brand image that a product has, the greater the consumer's interest in buying and using products from that brand [10].

Brand image is a set of beliefs, ideas, and impressions that a person has towards a brand [11]. The reputation of the brand will affect the consumer's view of a product, so the reputation of the brand must create a positive image in the mind of the consumers. According to Hawkins, Best, and Coney, brand image is a perception in the minds of consumers about the good impression of a brand [12]. This good impression will be created if the brand has unique advantages, good reputation, popular and trustworthy. The brand image itself has the potential to influence consumers' perceptions and expectations about the goods and services and ultimately affects customer satisfaction. Some previous research results show that brand image has a significant influence on customer satisfaction [13].

Satisfaction is a feeling of pleasure or disappointment that appears after comparing the expected performance of products to the actual performance. If performance is below expectations, the customer is not satisfied; if the performance meets expectations, the customer is satisfied; and if the performance exceeds expectations, the customer is very satisfied or happy [4]. While Lovelock and Wirtz state that satisfaction is an attitude decided based on the experience gained. Satisfaction is an evaluation of characteristics or services that provide a level of customer pleasure related to the fulfilment of customer consumption needs [14]. Customer satisfaction can be created through quality, service, and 
value. The key to generating customer loyalty is by providing high customer value. Customer satisfaction can be measured through three indicators. First is the overall customer satisfaction. To measure overall customer satisfaction is to divide it into two parts of the measurement process, namely: measuring the level of customer satisfaction with the product concerned, and assessing and comparing with the overall customer satisfaction level with competing products. Second is the confirmation of expectation. In this concept, satisfaction is not measured directly but concluded based on the suitability or mismatch between customer expectations with the actual results felt. Finally, it is by comparing to the ideal state, in which the actual result of a product is compared to the ideal product according to consumer perception.

Besides influencing consumer satisfaction, brand image can also influence purchase decisions. Kotler and Keller explain that purchasing decisions are consumer decisions regarding preferences for brands in a collection of choices [4]. Indicators used in measuring purchasing decisions are the desire to use the product, the desire to own the product, interest in the product, willingness to sacrifice (time, cost, energy) to obtain a product, and know the function of the product with well.

With the increasing use of skin care products in Indonesia and the support to use domestic products, this study will examine the effect of country of origin image on purchase decisions through brand image and its impact on customer satisfaction for local brand skin care products in Indonesia.

\subsection{Research framework}

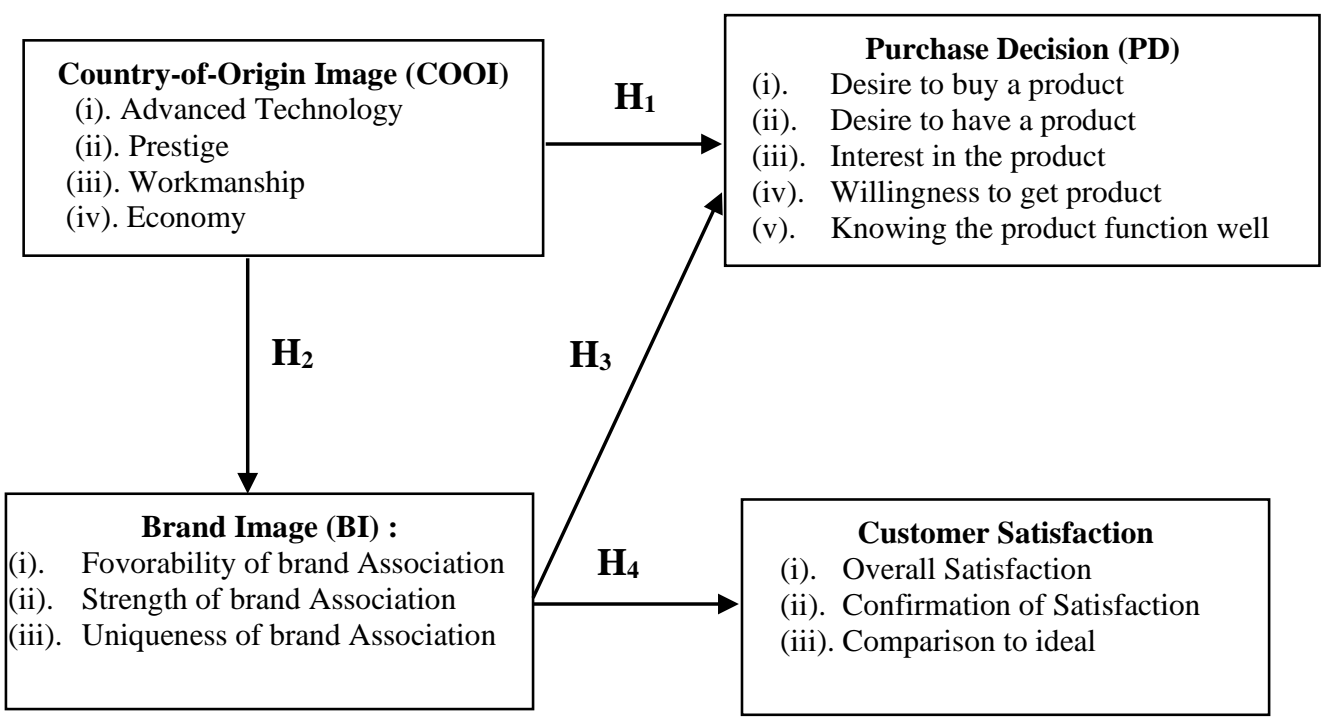

Fig. 1. Research framework

\section{Research method}

This research uses a quantitative method. The population in this study is the consumers who buy and use skin care products from local Indonesian brands, with a sample size of 179 respondents. The sampling method used in this study is a non-probability sampling with the purposive sampling technique. The sample of this study is taken with certain criteria, such 
as the consumers living in Surabaya, who have bought and used skin care products from local Indonesian brands for the duration of a year.

The source of this research primary data is obtained from the questionnaire. The answers also include several questions on respondent's personal data as well as answers related to the research variables, namely country of origin image, brand image, purchase decision, and customer satisfaction. This research uses a Likert scale to answer the statements in the questionnaire. Each answer is given a score or a value starting from the number 1 (strongly disagree) to 5 (strongly agree).

The data obtained is then processed using a PLS (Partial Least Square) software, which consists of a measurement model (outer model) and a structural model (inner model). The measurement model aims to show how the manifest variable is the latent variable to be measured, while the structural model aims to show the strength of the latent or construct estimation variable, the latent variable formed in the PLS indicator is reflective and formative. In this study, the indicator used is a reflective indicator. Reflection indicators are indicators that are seen as indicators that are influenced by latent variables or indicators that are seen to reflect, represent, and observe the effects caused by latent variables [15].

\section{Analysis and discussion}

\subsection{Outer model evaluation}

A validity test is done to measure the validity of the questionnaire. The following are the results of the test using the partial least square with a sample of 179 people.

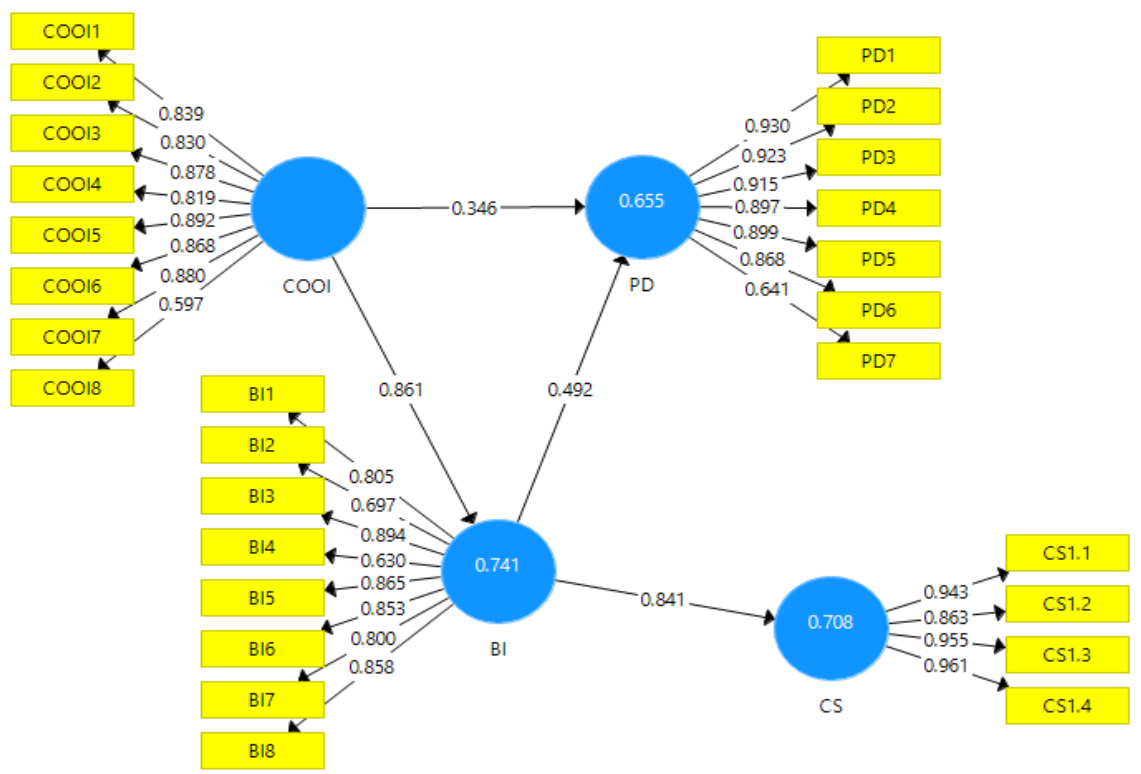

Fig. 2. PLS Algorithm Test

The Outer Model is often called the outer relation or measurement model with the aim of specifying the relationship between the variables studied and their indicators. The model test must first be conducted to verify the indicators and latent variables that can be tested subsequently. The tests include testing the construct validity (convergent and discriminant) and construct reliability. The information is as follows: 


\subsubsection{Convergent validity test}

A construct indicator is said to meet the convergent validity if it has a loading value $>0.50$ [16]. Table 1 shows the results of testing the country of origin image, brand image, purchase decision and customer satisfaction. The loading factor in the original sampling can be seen that all construct indicators of each variable have a loading factor greater than 0.50 . Thus the indicators can be declared valid to measure its latent variable.

Table 1. Convergent validity

\begin{tabular}{lcccc}
\hline & $\begin{array}{c}\text { Country of Origin } \\
\text { Image }\end{array}$ & $\begin{array}{c}\text { Brand } \\
\text { Image }\end{array}$ & $\begin{array}{c}\text { Purchase } \\
\text { Decision }\end{array}$ & $\begin{array}{c}\text { Customer } \\
\text { Satisfaction }\end{array}$ \\
\hline COOI1 & 0.839 & & & \\
COOI2 & 0.830 & & & \\
COOI3 & 0.878 & & & \\
COOI4 & 0.819 & & & \\
COOI5 & 0.892 & & & \\
COOI6 & 0.868 & & & \\
COOI7 & 0.880 & 0.805 & & \\
COOI8 & 0.597 & 0.697 & & \\
BI1 & & 0.894 & & \\
BI2 & & 0.630 & & \\
BI3 & & 0.865 & & \\
BI4 & & 0.853 & & \\
BI5 & & 0.800 & & \\
BI6 & & 0.858 & & \\
BI7 & & & 0.930 & \\
BI8 & & & 0.923 & \\
PD1 & & & 0.915 & \\
PD2 & & & 0.897 & \\
PD3 & & & 0.899 & \\
PD4 & & & 0.868 & \\
PD5 & & & 0.641 & \\
PD6 & & & & \\
PD7 & & & & \\
CS1 & & & & \\
CS2 & & & & \\
CS3 & & & & \\
CS4 & & & & \\
\hline & & & & \\
\hline
\end{tabular}

\subsubsection{Discriminant validity test}

Discriminant validity of each variable in measuring the items of this statement is indicated by their cross-loadings. Table 2 shows that each indicator has a cross-loading value (of the measured dimensions or variables) greater than the values of other dimensions or variables. So, all indicators are valid to measure the dimensions or variables as the value of cross loading $>0.50$. If the correlation value of the indicator is higher to the construct itself than the correlation of the indicator to the other constructs, it can be concluded that the latent construct predicts the indicator on each indicator better than to other indicators [16]. 
Table 2. Cross loading of each indicator

\begin{tabular}{lllll}
\hline & BI & COOI & CS & PD \\
\hline BI1 & $\mathbf{0 . 8 0 5}$ & 0.696 & 0.73 & 0.655 \\
BI2 & $\mathbf{0 . 6 9 7}$ & 0.488 & 0.494 & 0.473 \\
BI3 & $\mathbf{0 . 8 9 4}$ & 0.799 & 0.822 & 0.745 \\
BI4 & $\mathbf{0 . 6 3 0}$ & 0.445 & 0.383 & 0.402 \\
BI5 & $\mathbf{0 . 8 6 5}$ & 0.782 & 0.723 & 0.741 \\
BI6 & $\mathbf{0 . 8 5 3}$ & 0.753 & 0.740 & 0.710 \\
BI7 & $\mathbf{0 . 8 0 0}$ & 0.735 & 0.684 & 0.590 \\
BI8 & $\mathbf{0 . 8 5 8}$ & 0.733 & 0.702 & 0.664 \\
COOI1 & 0.646 & $\mathbf{0 . 8 3 9}$ & 0.653 & 0.577 \\
COOI2 & 0.716 & $\mathbf{0 . 8 3 0}$ & 0.633 & 0.611 \\
COOI3 & 0.716 & $\mathbf{0 . 8 7 8}$ & 0.725 & 0.681 \\
COOI4 & 0.665 & $\mathbf{0 . 8 1 9}$ & 0.604 & 0.581 \\
COOI5 & 0.806 & $\mathbf{0 . 8 9 2}$ & 0.798 & 0.680 \\
COOI6 & 0.793 & $\mathbf{0 . 8 6 8}$ & 0.802 & 0.707 \\
COOI7 & 0.787 & $\mathbf{0 . 8 8 0}$ & 0.819 & 0.750 \\
COOI8 & 0.544 & $\mathbf{0 . 5 9 7}$ & 0.499 & 0.474 \\
CS1 & 0.781 & 0.761 & $\mathbf{0 . 9 4 3}$ & 0.804 \\
CS2 & 0.737 & 0.783 & $\mathbf{0 . 8 6 3}$ & 0.701 \\
CS3 & 0.794 & 0.783 & $\mathbf{0 . 9 5 5}$ & 0.805 \\
CS4 & 0.819 & 0.815 & $\mathbf{0 . 9 6 1}$ & 0.793 \\
PD1 & 0.725 & 0.697 & 0.777 & $\mathbf{0 . 9 3 0}$ \\
PD2 & 0.734 & 0.726 & 0.784 & $\mathbf{0 . 9 2 3}$ \\
PD3 & 0.733 & 0.677 & 0.793 & $\mathbf{0 . 9 1 5}$ \\
PD4 & 0.673 & 0.663 & 0.723 & $\mathbf{0 . 8 9 7}$ \\
PD5 & 0.716 & 0.719 & 0.812 & $\mathbf{0 . 8 9 9}$ \\
PD6 & 0.658 & 0.645 & 0.700 & $\mathbf{0 . 8 6 8}$ \\
PD7 & 0.565 & 0.555 & 0.455 & $\mathbf{0 . 6 4 1}$ \\
\hline
\end{tabular}

\subsubsection{Reliability test}

This study uses alpha coefficient or Cronbach's alpha to measure the reliability or consistency between questions in an instrument. Based on the results, it is said to be reliable if the alpha coefficient value is greater than 0.5 [16]. Table 3 shows that the value of internal consistency reliability, or the alpha coefficient of each variable in each variable, is declared reliable because the value is greater than 0.5 . Thus the measurement items on each variable are reliable to be used in this research.

Table 3. Reliability Test

\begin{tabular}{lcc}
\hline & Cronbach Alpha & Composite Reliability \\
\hline Country of origin image & 0.934 & 0.946 \\
Brand image & 0.921 & 0.936 \\
Purchase decision & 0.945 & 0.957 \\
Customer satisfaction & 0.948 & 0.963 \\
\hline
\end{tabular}

\subsubsection{Average Variance Extracted (AVE)}

Average Variance Extracted (AVE) is one of the validity test requirements based on the extracted average value of each variable. AVE value higher than 0.5 indicates that it has met the evaluation of convergent validity [16]. Table 5 shows the AVE test results. 
Table 4. AVE Test

\begin{tabular}{lc}
\hline & AVE \\
\hline Country of origin Image & 0.690 \\
Brand image & 0.648 \\
Purchase decision & 0.762 \\
Customer satisfaction & 0.867 \\
\hline
\end{tabular}

\subsection{Goodness of inner model evaluation}

The goodness of the inner model is used to determine the ability of endogenous variables to explain exogenous variables and to specify the influence between variables. Variables that have $R^{2}$ results greater than 0.67 indicate that the model is "strong," $R^{2}$ greater than 0.33 indicates that the model is "moderate," $\mathrm{R}^{2}$ greater than 0.19 indicates the "weak" model [17]. The results of the goodness of inner models shown through $\mathrm{R}^{2}$ are presented in Table 5 .

Table 5. R-Square

\begin{tabular}{lc}
\hline & R Square \\
\hline Brand image & 0.741 \\
Purchase Decision & 0.655 \\
Customer satisfaction & 0.708 \\
\hline
\end{tabular}

The R-square brand image value of 0.741 shows the country of origin image variable can influence brand image strongly. The R-square result of the purchase decision of 0.655 shows that the country of origin image and brand image variables can influence the purchase decision moderately. The result of customer satisfaction R-square of 0.708 shows that the brand image variable can affect customer satisfaction strongly.

\subsection{Hypothesis testing}

This hypothesis test is to determine the causality which is developed in the model, namely the influence of exogenous variables on endogenous variables. Testing of significance can be known through T-statistics greater than the critical value of 1.96 in Figure 3 and Table 6 below:

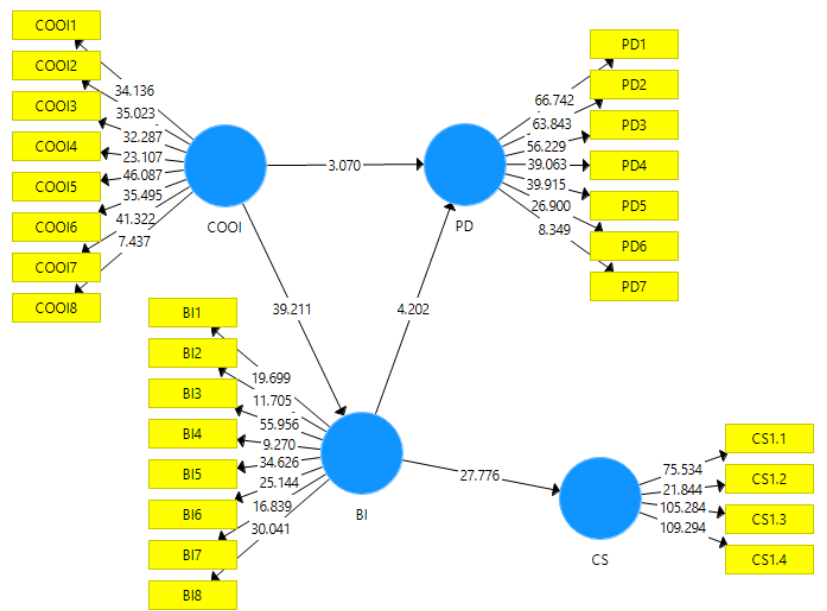

Fig. 3. Bootstrapping 
Table 6. Path coefficients

\begin{tabular}{lccccc}
\hline & $\begin{array}{c}\text { Original } \\
\text { Sample }\end{array}$ & $\begin{array}{c}\text { Sample } \\
\text { Rata-rata }\end{array}$ & $\begin{array}{c}\text { Standard } \\
\text { Deviation }\end{array}$ & $\begin{array}{c}\text { T- } \\
\text { statistics }\end{array}$ & P Value \\
\hline Country of Origin Image $\rightarrow$ Brand Image & 0.861 & 0.864 & 0.022 & 39.211 & 0.000 \\
Country of Origin Image $\rightarrow$ Purchase Decision & 0.346 & 0.348 & 0.113 & 3.070 & 0.002 \\
Brand Image $\rightarrow$ Purchase Decision & 0.492 & 0.496 & 0.117 & 4.202 & 0.000 \\
Brand Image $\rightarrow$ Customer Satisfaction & 0.841 & 0.846 & 0.030 & 27.776 & 0.000 \\
\hline
\end{tabular}

From Table 7, it can be explained the influence of the independent variables on the dependent variable in each of the hypotheses below:

\subsubsection{Country of origin image influences brand image}

The result of the test shows that the country of origin image t-statistic value to the brand image is 39.211 , higher than 1.96. It is positive or in the same direction. This can be interpreted that the country of origin image has a significant and positive influence on brand image, so $\mathrm{H} 1$ is accepted. This shows that before consumers make any purchasing decisions, the consumers tend to see where the product is from. Then, the consumers will see the brand image of the product that is related to the name, quality, and price of the brand.

The influence of the country of origin image on the brand image can be seen from the highest mean. The high purchase power of consumers in Indonesia for skin care products affects local skin care producers in making products at affordable prices, which interests the consumers. The result of this research is in line with a previous study conducted by Diamantopoulus, Schlegelmilch, and Palihawadana which conduct research on 300 UK consumers to show the indirect effect of the country of origin image on purchasing intentions because the influence is fully mediated by the brand image [8]. That study specifically explains that the role of country of origin image is not only as a driver of product image but also as a driver of brand image.

\subsubsection{Country of origin image affects purchase decision}

The result of the test shows that the country of origin image t-statistic value to the purchase decision is 3.070 , higher than 1.96. It is positive or in the same direction. This can be interpreted that the country of origin image has a significant and positive effect on the purchase decision, so $\mathrm{H} 2$ is received. This shows that consumer buying decision is influenced by the image factor of a country that manufactures the product (country of origin image). This country of origin image can be shaped from the previous experience of visiting the country or the experience of using products from that country.

The result of this study is in line with previous studies by Genç and Bayraktaroğlu and Durmaz and Yildiz, who examine the effect of country of origin image in specific contexts of developing countries $[18,19]$. In their researches, individual effects and social effects shape the country of origin image. The country of origin image itself is found to influence product evaluation and lead to actual purchasing decisions.

\subsubsection{Brand image affects purchase decision.}

From the test results listed in Table 6, the t-statistic of the brand image on the purchase decision is 4.202. The t-statistic value is higher than 1.96 and has a positive direction. This can be interpreted that the brand image has a significant and positive direct influence on the purchase decision, so $\mathrm{H} 3$ is accepted. This shows that a good brand image will make consumers the purchase decisions. New consumers also tend to buy a product with a good brand image to avoid taking the risk of buying. 
The result of this research is in line with the study of Yen which examines the moderating effect of consumer ethnocentrism on willingness to buy domestic products in developing countries [20]. With the sample of 385 consumers, the results reveal that the consumer ethnocentrism, perceived quality, perceived price, and brand image significantly influence the willingness and decision to buy domestic products [20].

\subsubsection{Brand image affects customer satisfaction}

In the test results listed in Table 6, the t-statistic of the brand image to the customer satisfaction is 27.776 higher than 1.96 with a positive direction. This can be interpreted that the brand image has a positive significant effect on the customer satisfaction, so H4 is accepted. This shows that a good brand image will affect the level of customer satisfaction after using the product. The result of this research is in line with the research of Elsäßer and Wirtz which examines the success factors of branding on customer satisfaction and brand loyalty [21]. The results show that the brand image and the image of the country of the product maker are the dimensions that positively affect the customer satisfaction and the brand loyalty.

Table 7. Indirect Effect

\begin{tabular}{l}
\hline Effect \\
$\begin{array}{l}\text { Country of origin image }(\mathrm{COOI}) \rightarrow \text { brand image } 0.861 \times 0.492=0.423612(\mathrm{BI}) \rightarrow \text { purchase decision } \\
(\mathrm{PD})\end{array}$
\end{tabular}

Table 7 shows the value of the indirect effect between the country of origin image and the purchase decisions through the brand image of 0.423 , which is greater than the direct effect of only 0.346 . This means that brand image mediates the influence of country of origin image on purchase decisions.

\section{Conclusions}

This study examines the influence of the country of origin image on the purchase decisions through the brand image and its impact on customer satisfaction on the local brand skin care products in Indonesia. The results prove that the country of origin image has a positive and significant effect on the purchase decision and on the brand image. The brand image has a positive and significant effect on purchase decisions and on customer satisfaction. The results also show that the brand image plays a role in mediating the influence of country of origin image on the purchase decisions.

The important role of the country of origin image and the brand image on the purchase decisions and customer satisfaction makes skincare producers in Indonesia need to pay more attention to several aspects of prestige, uniqueness, and convenience to obtain their products. Prestige aspects can be achieved by improving the products both in terms of packaging to quality.

Indonesian local skin care producers also need to create uniqueness in brand associations in order to create strong associations in the minds of consumers and attract consumers to buy these products. This can be done by innovating the product. Innovative and unique products will form a good exclusivity of brand association with consumers. Indonesian local skin care producers also need to make the products obtainable for consumers to make purchases, so it no longer makes consumers spend time to find the desired skin care products. This can also be done by increasing the distribution network. 


\section{References}

1. ZAP Clinic, Zap Beauty Index 2018, Jakarta: MarkPlus Inc. (2018). p. 1-33. [in Bahasa Indonesia]. https://zapclinic.com/zap-beauty-index-download

2. C. Adina, C. Gabriela, S. Roxana-Denisa, Procedia Economics and Finance, 23:422427(2015). https://www.sciencedirect.com/science/article/pii/S2212567115003834

3. M.F. Herz, A. Diamantopoulos, Journal of International Marketing, 21,3:95121(2013). https://journals.sagepub.com/doi/abs/10.1509/jim.13.0004

4. P. Kotler, K.L. Keller, Marketing Management, Upper Saddle River, N.J.: Pearson/Prentice Hall (2012). https://trove.nla.gov.au/work/4070618

5. I.M Martin, S. Eroglu, Journal of Business Research, 28,3:191-210(1993).

6. N. Souiden, F. Pons, M.E. Mayrand, Journal of Product \& Brand Management, 20,5:356-367(2011). https://www.emeraldinsight.com/doi/abs/10.1108/10610421111157883

7. M.R. Czinkota, I.A. Ronkainen, International marketing, USA: Cengage Learning (2013).

https://books.google.co.id/books?hl=en\&lr=\&id=kSYXAAAAQBAJ\&oi=\&redir_esc $=\mathrm{y}$

8. A. Diamantopoulus, B. Schlegelmilch, P. Palihawadana, International Marketing Review 28,5:515-521(2011). https://www.emeraldinsight.com/doi/abs/10.1108/02651331111167624

9. T.C Garrett, S. Lee, K. Chu, International Marketing Review, 34,2:272-292(2017). https://www.emeraldinsight.com/doi/abs/10.1108/IMR-03-2015-0083

10. K.L. Keller, Journal of Marketing Communications, 15,2-3:139-155(2009). https://www.tandfonline.com/doi/abs/10.1080/13527260902757530

11. P. Kotler, V. Wong, J. Saunders, G. Armstrong, Principles of Marketing. England: Pearson Education, Inc (2005). https://kar.kent.ac.uk/32908/

12. D.I. Hawkins, R.J. Best, K.A. Coney, Consumer Behaviour: Implications for Marketing Strategy, Boston USA: Richard D. Irwin Inc (1992). https://trove.nla.gov.au/work/9836823

13. M. Rambocas, V.M. Kirpalani, E. Simms, International Journal of Bank Marketing, 36,1:19-40(2018). https://www.emeraldinsight.com/doi/abs/10.1108/IJBM-09-2016$\underline{0139}$

14. C.H. Lovelock, J. Wirtz, Service Marketing (People, Technology, Strategy). USA: World Scientific Publishing (2016). https://books.google.co.id/books?hl=en\&lr=\&id=dKJIDQAAQBAJ\&o

15. K.A. Bollen, S. Bauldry, Causal Indicators, Composite Indicators, and Covariates. Psychol Methods, 16,3:265-284(2011).https://psycnet.apa.org/record/2011-15038-001

16. J.F. Jr. Hair, W.C. Black, B.J. Babin, R.E. Anderson, Multivariate Data Analysis: A Global Perspective, Upper Saddle River, NJ: Prentice Hall (2010). https://is.muni.cz/el/1423/podzim2017/PSY028/um/_Hair_-

Multivariate data analysis 7 th revised.pdf

17. W.W. Chin, Issues and opinion on structural equation modeling, 22,1:7-16(1998). https://www.jstor.org/stable/249674

18. B. Genç, A. Gül Bayraktaroğlu. Qualitative Consumer Research, 14, 1:25-50(2017). https://www.emeraldinsight.com/doi/full/10.1108/S1548-643520170000014005

19. Y. Durmaz, B. Yildiz, International Journal of Academic Research in Management and Business, 1,2:44-54(2016). https://halshs.archives-ouvertes.fr/halshs-01360486/

20. Y.S. Yen. Asia Pacific Journal of Marketing and Logistics, 30,4:907-926(2018). https://www.emeraldinsight.com/doi/abs/10.1108/APJML-09-2017-0226 
21. M. Elsäßer, B.W. Wirtz, Journal of Business \& Industrial Marketing, 32,1:138152(2017). https://www.emeraldinsight.com/doi/abs/10.1108/JBIM-05-2015-0101

22. K.L. Keller,Strategic Brand Management: Building, Measuring, And Managing Brand Equity, England: Pearson Education, Inc (2008).

https://www.pearson.com/us/higher-education/program/Keller-Strategic-BrandManagement-4th-Edition/PGM152495.html 